\title{
THE EFFECT OF RECRYSTALLIZATION ANNEALING ON CORROSION BEHAVIOR OF MARINE ALUMINUM ALLOYS IN TIGRIS RIVER
}

\author{
*Israa R. Mohammed ${ }^{1}$
}

Sahib M. Mahdi

1) Department of material engineering, college of engineering, Mustansiriyah University, Baghdad, Iraq

2) Department of material engineering, college of engineering, Mustansiriyah University, Baghdad, Iraq

\begin{abstract}
In the present work the mechanical properties and corrosion behavior of both aluminum magnesium alloy grade 5083 and 5086 were studied in Tigris River at the beach, before and after recrystallization annealing at room temperature $\left(23{ }^{\circ} \mathrm{C}\right)$. The corrosion resistance of both alloys decrease after these alloys were recrystallization annealed at temperature of $350{ }^{\circ} \mathrm{C}$ for $25 \mathrm{~min}$ for 5083 this increasing was from $2.493 \times 10^{-3}$ to $51.24 \times 10^{-3}$ and for 5086 it was from $187.7 \times 10^{-6}$ to 24.41 $\times 10^{-3}$ both alloys will suffer from localized corrosion as a result of recrystallization annealing. The yield, tensile stress and hardness of both alloys decrease, the tensile stress of 5083 decrease in the percentage of $9.8 \%$, while the yield decrease in the percentage of $15 \%$

For 5086 it was $5.071 \%$ and $10 \%$ respectively while the elongation of both alloys increase in the percentage of $20 \%$. The hardness of 5083 and 5086 increase in the percentage of $17.6 \%$ and $23 \%$ respectively.
\end{abstract}

Keywords: marine aluminum alloy; recrystallization annealing; mechanical properties

\section{Introduction}

After oxygen and silicon, aluminum is the third abundant element and in planet aluminum is the most abundant metal. Aluminum is nontoxic, recycled, and it is high resistance to corrosion so it is used in wide range of application like in marine application. The Scientists interest in decreasing the ships weight so they found aluminum is the best choice. Aluminum use in ships and boat began at (1960) [1]. In Asia and north America marine aluminum used in fishing boat and in fast vessels [2], aluminum alloys used in long ships building [3].. The aluminum alloy grade (5145) is the most used alloy in the past due to their good resistance to corrosion and good strength [4]. Nowadays, the (5xxx) marine aluminum alloy is used in wide range of application like in (marine, automotive and in the industry of the construction) due to its high ratio of weight to strength and high elasticity [5]. These alloy are used in ships building as plate or sheet and it can be used in whole weld construction because of their high resistance to corrosion and their mild strength [6-8]. Another reason that make aluminum best choice in marine application is the low density of aluminum (2.7) $\mathrm{g} / \mathrm{cm}^{3}$ [9]. Steel can also be used in marine application but the major problem in steel is it high weigh, so by replacing steel by aluminum the weight of ship will reduced by $(50 \%)$ and in the case of ship's hull the weight decreased by $(60 \%)$, so the stability of ship increased and thus allow the design of narrow ships [10]. Marine aluminum alloy grade (5083) is the most used alloy for ship building [11]. The mechanical properties of marine aluminum alloy can be alter by heat treatment processes [12]. Marine aluminum alloy grade (5083, 5086 and 5456) become more sensitized after exposure to 
temperature of (65 to 250 ) $\mathrm{C}^{0}$ for short time period. During a recrystallization anneal, new grains form in a cold-worked metal. These new grains have a greatly reduced number of dislocations compared to the cold-worked metal. This change returns the metal to its pre-coldworked state, with lower strength and increased ductility

In the present work effect of recrystallization annealing on the mechanical properties and corrosion resistance of marine aluminum alloy grade (5083 and 5086) have been investigated by using cycle polarization, hardness and tensile test.

\section{Materials and method}

\subsection{Aluminum alloys}

The materials used in the present work are marine aluminum alloys grade (5083 and 5086) plate of $(50 \times 50 \times 2.5 \mathrm{~cm})$. The chemical composition of these alloys were analyzed by the using of spectro max and the results are listed in "Table 1 " the results were match to the standard values [13]. This study was conducted at Tigris River. The method of water jet was used to cut the plate to fit samples holder dimensions the dimension and design of the samples holder is listed in "fig. 1 ".

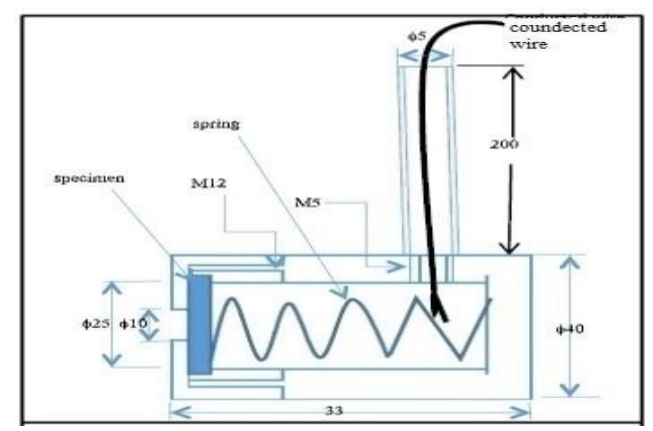

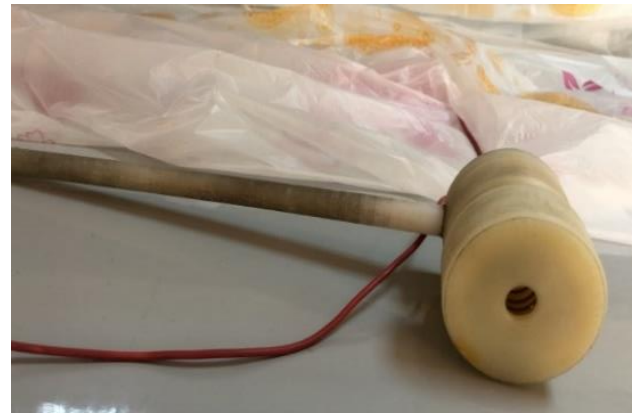

Figure 1. Design and dimensions of specimen holder. All dimensions in $\mathrm{mm}$

\subsection{Water media}

In this study Tigris River was selected as water media in order to investigate the effect of recrystallization annealing on the corrosion and mechanical properties of both 5083 and 5086 marine aluminum alloys. The work was done at room temperature $\left(23{ }^{0} \mathrm{C}\right)$.

With salinity of $(625 \mathrm{mg} / \mathrm{L})$. The chemical analysis of water media is listed in "Table 2".

\subsection{Heat treatment}

In this study both 5083 and 5086 marine aluminum alloys were annealed by recrystallization annealing to study the impact of heat treatment on the corrosion resistance and mechanical properties of these alloys. For recrystallization annealing, the samples were placed in the lab furnace at a temperature of $\left(350^{\circ}\right.$ C) for $20 \mathrm{~min}$ and then they were left for around six hours to cooled down in the furnace.

\subsection{Corrosion test}

Polarization cycle test had been utilized to study the corrosion behavior of 5083 and 5086 marine aluminum alloys before and after heat treatment. Before these tests all samples were grinding using emery papers with different grade (300, 500, 1000 and 1500) and then polished. Samples with $0.78 \mathrm{~mm}^{2}$ surface area were exposed to Tigris water media before and after recovery annealing. The experimental work was carried out in three electrode corrosion cell with marine 
aluminum working electrode, graphite counter

electrode and calomel reference electrode.

Table 1. Chemical analysis of the marine aluminum alloys

\begin{tabular}{lccccccccccc}
\hline Alloy & Si \% & Fe \% & $\mathrm{Cu} \%$ & $\mathrm{Mn} \%$ & $\mathrm{Mg} \%$ & $\mathrm{Cr} \%$ & $\mathrm{Ni} \%$ & $\mathrm{Ti} \%$ & $\mathrm{Zn} \%$ & $\mathrm{~Pb} \%$ & $\mathrm{Al} \%$ \\
\hline 5083 & 0.15 & 0.368 & 0.022 & 0.417 & 3.8 & 0.140 & 0.002 & 0.019 & 0.010 & 0.019 & 95 \\
5086 & 0.06 & 0.28 & 0.001 & 0.20 & 3.11 & 0.074 & 0.010 & 0.011 & 0.006 & 0.033 & 96 \\
\hline
\end{tabular}

Table 2. Chemical analysis of Tigris River

\begin{tabular}{lcclllllllll}
\hline chemical & $\mathrm{PH}$ & $\mathrm{EC}$ & $\begin{array}{l}\text { T.D.S } \\
(\mathrm{Mg} / \mathrm{l})\end{array}$ & $\begin{array}{l}\mathrm{CO}_{3} \\
(\mathrm{Mg} / \mathrm{l})\end{array}$ & $\begin{array}{l}\mathrm{HCO}_{3} \\
(\mathrm{Mg} / \mathrm{l})\end{array}$ & $\begin{array}{l}\mathrm{Ca} \\
(\mathrm{Mg} / \mathrm{l})\end{array}$ & $\begin{array}{l}\mathrm{Mg} \\
(\mathrm{Mg} / \mathrm{l})\end{array}$ & $\begin{array}{l}\mathrm{Cl} \\
(\mathrm{Mg} / \mathrm{l})\end{array}$ & $\begin{array}{l}\mathrm{NO}_{3} \\
(\mathrm{Mg} / \mathrm{l})\end{array}$ & $\begin{array}{l}\mathrm{Na} \\
(\mathrm{Mg} / \mathrm{l})\end{array}$ & $\begin{array}{l}\mathrm{K} \\
(\mathrm{Mg} / \mathrm{l})\end{array}$ \\
\hline content & 7.3 & 955 & 625 & 0.0 & 366 & 47 & 19 & 142 & 1.1 & 115 & 2 \\
\hline
\end{tabular}

\subsection{Tensile test}

To study the effect of recrystallization annealing on the tensile properties, the plate were formed according to ASTM standard sample with $50 \mathrm{~mm}$ gage length as shown in "fig. 2". Figure 3 shows tensile device that had been utilized in this study. Figure 4 shows stress - strain curve

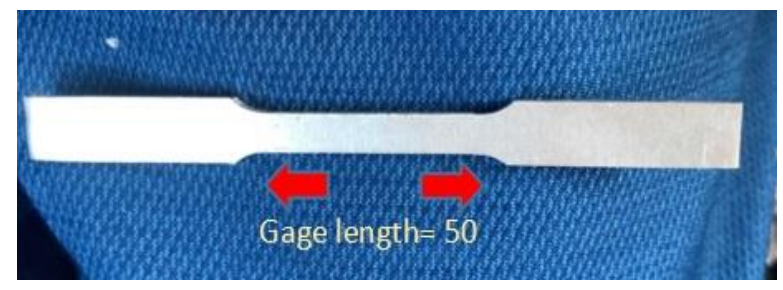

Figure 2. Tensile test specimen with gage length of 50 $\mathrm{mm}$

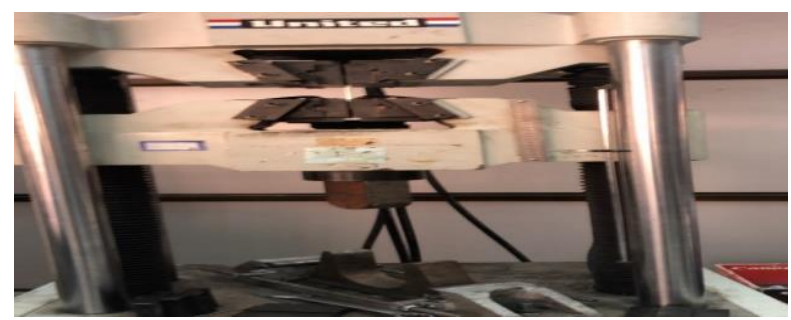

Figure 3. Tensile test device

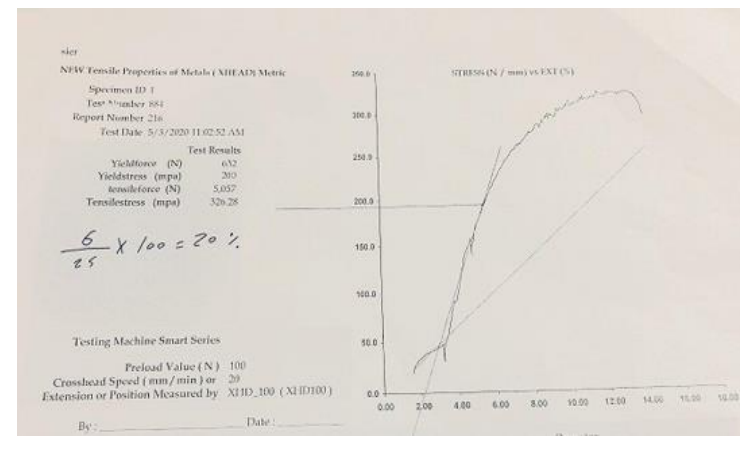

(a)

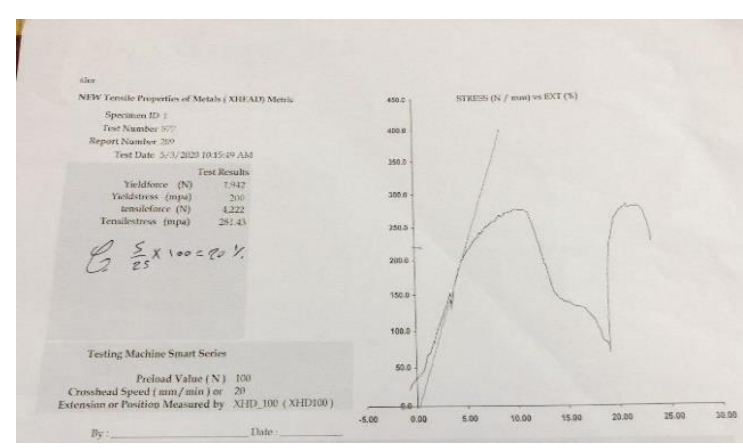

(b)

Figure 4. Stress - strain curve of both 5083 and 5086; a) 5083 alloy; b) 5086 alloy

\section{Results}

\subsection{Effect of recrystallization annealing on tensile} properties of 5083 and 5086 marine aluminum alloys

The tensile behavior of both 5083 and 5086 marine aluminum alloys before and after heat 
treatment is shown in "fig. 5" in which the blue line represent tensile stress, red line represent yield stress and black line represent elongation . From this figure both yield and tensile stress decreases after heat treatment. For 5083 alloy this decreasing in tensile stress was from (326 to 294 $\mathrm{MPa}$ ), while the decreasing in yield stress was from (200 to $170 \mathrm{MPa}$ ). The reason for this decreasing is that, dislocation density alter during the recrystallization annealing.
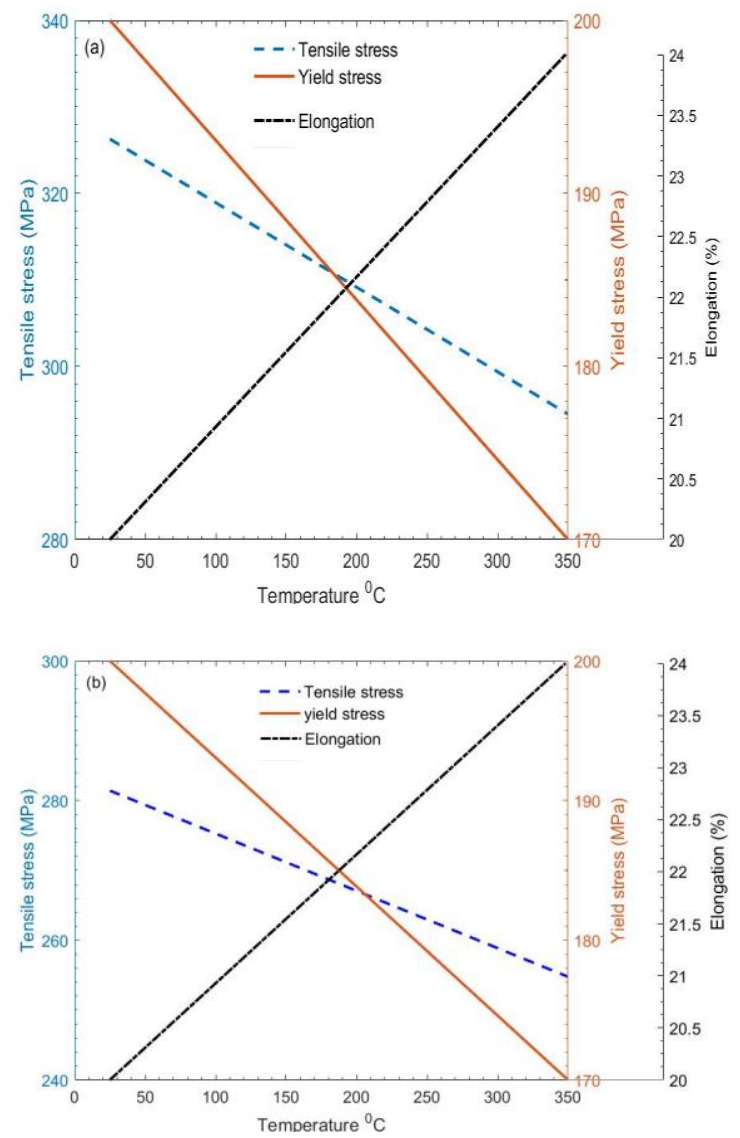

Figure 5. Tensile behavior of both 5083 and 5086 before and after heat treatment: a) 5083 alloy, b) 5086 alloy

The elongation for both alloys increase. This increase was from (22 to 24\%) for both alloys, the elongation increase as a result of rearrangement of dislocation that occur during recrystallization annealing.
3.2 Effect of recrystallization annealing on hardness of 5083 and 5086 marine aluminum alloys

The effect of heat treatment on the hardness of both 5083 and 5086 alloys is listed in "Table 3". From this table the hardness of both alloys decreased. This decreasing result from the softening that occur during annealing at temperature of $350{ }^{0} \mathrm{C}$ and the hardness of samples that had been annealed is controlled by friction of recrystallized grains.

Table 3. Hardness of both 5083 and 5086 before and after recrystallization annealing

\begin{tabular}{lll}
\hline Alloys & $\begin{array}{l}\text { Before } \\
\text { recrystallization } \\
\text { annealing }\end{array}$ & $\begin{array}{l}\text { after recrystallization } \\
\text { annealing }\end{array}$ \\
\hline 5083 & $85 \mathrm{HV}$ & $70 \mathrm{HV}$ \\
5086 & $105 \mathrm{HV}$ & $80 \mathrm{HV}$ \\
\hline
\end{tabular}

\subsection{Effect of recrystallization annealing on the corrosion resistance of $\mathbf{5 0 8 3}$ and 5086 marine aluminum alloys}

"Fig. 6" represent the typical polarization curve of both 5083 and 5086 marine aluminum alloys in Tigris River at temperature of 25 for as received samples and $350{ }^{\circ} \mathrm{C}$ for recrystallization annealed samples at distance of $15 \mathrm{~m}$ from the beach. Potential of corrosion ( $\left.\mathrm{E}_{\mathrm{corr}}\right)$ and corrosion rate of these alloys are listed in "Table 3". From these figure and table it is clear that 5083 have lower corrosion resistance than 5086, This difference in the corrosion resistance of these alloys is result from the difference in the characteristics of particles of these alloys [14]. Also 5083 have higher percentage of $\mathrm{Mg}$, which will make this alloy susceptible to corrosion [15]. After annealing 5083 and 5086 alloys at $350{ }^{\circ} \mathrm{C}$ for $25 \mathrm{~min}$ it had been observed that $\mathrm{E}_{\text {corr }}$ shift to more negative value and the corrosion rate increase and since, therefore 5083 and 5086 alloys, corrosion resistance will decrease when subjected to recrystallization annealing. The 
microstructure of these alloys consist of intermetallic and solid solution particles, when these alloys heated at low temperature, these particles will remain undissolved. Fine participate and coarse metallic particles can formed in aluminum alloys as a result of intermetallic particles grouping [16]. Fine participate will form during aging process, while during the solidification process, coarse intermetallic particles form [16]. These particles will play an important role in the corrosion of aluminum alloys. These particles are split into two group (noble and active particles). $\mathrm{Mg}$ particles in aluminum alloys are considered as an active particles, and act as anode and result in the corrosion increasing. Also PH content in water may affect the corrosion rate, when it is decrease the rate will increase.

"Fig. 6" and "Table 4" also show the current density of pitting. When the pitting current density decrease, the corrosion resistance of the protective layer $\left(\mathrm{Al}_{2} \mathrm{O}_{3}\right)$ increase. From this figure and table, when the temperature increase the current density of pitting increase which indicate that the protective layer failed to protect the metal from the corrosion.

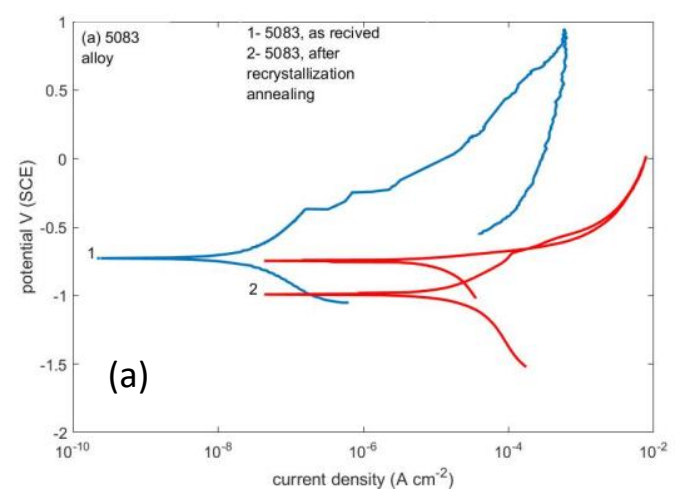

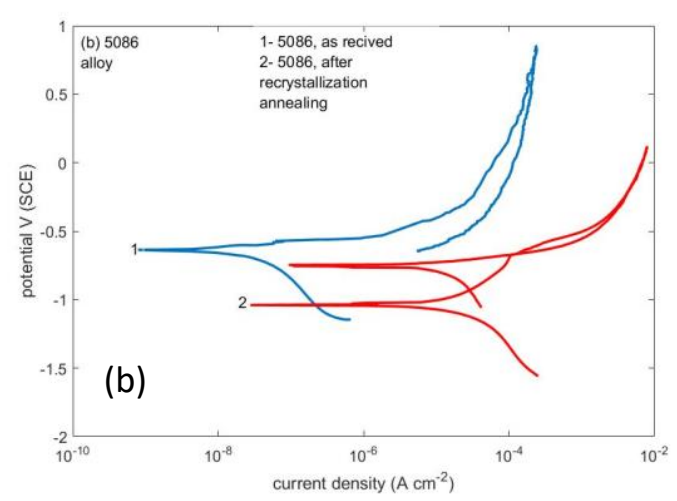

Figure 6. Potentiodynamic polarization curves for; a) 5083 alloy in Tigris River at beach; b) 5086 alloy in Tigris River at beach

Table 4. Corrosion rate and corrosion potential obtained from polarization curve of 5083 and 5086 alloys

\begin{tabular}{ccccc}
\hline Alloy & $\begin{array}{c}\text { Temperature } \\
\left({ }^{0} \mathrm{C}\right)\end{array}$ & $\begin{array}{c}\mathrm{E}_{\text {corr }} \\
(\mathrm{V})\end{array}$ & $\begin{array}{c}\text { Corrosion } \\
\text { rate }(\mathrm{mmpy})\end{array}$ & $\begin{array}{c}\mathrm{I}_{\text {corr }} \\
(\mu \mathrm{A})\end{array}$ \\
\hline 5083 & 25 & -0.728 & $2.493 \times 10^{-3}$ & 0.123 \\
& 350 & -0.991 & $51.24 \times 10^{-3}$ & 2.540 \\
5086 & 25 & -0.636 & $187.7 \times 10^{-6}$ & 0.9 \\
& 350 & -1.040 & $24.41 \times 10^{-3}$ & 1.210 \\
& & & & \\
\hline
\end{tabular}

\section{Conclusions}

1- the hardness of both alloys decrease as a result of recrystallization annealing

2- the tensile and yield stress will decrease as a result of recrystallization annealing

3- the corrosion resistance of both alloys decrease after recrystallization annealing, which indicate that this heat treatment is not suitable for improving the corrosion resistance of these alloys

4- 5086 alloy has better corrosion resistance than 5083 in Tigris River

\section{Acknowledgements}

The authors would like to thank the staff of

Mustansiriyah University, Baghdad-Iraq,

(www.upomustansiriyah.edu.iq) for their

support in the present work. 


\section{Conflict of interest}

The authors confirm that there is no conflict of interest.

\section{References}

1. Romhanji, E. and M. Popovic. (2006). Problems and prospect of Al-Mg alloys application in marine constructions. Journal of Metallurgy, Vol. 12, No. 4, pp. 297-307.

2. Sielski, R.A. (2008). Research needs in aluminum structure. Ships and Offshore Structures, Vol. 3, No. 1, pp. 57-65.

3. Gungor, B., et al. (2014). Mechanical and microstructural properties of robotic Cold Metal Transfer (CMT) welded 5083-H111 and 6082-T651 aluminum alloys. Materials \& Design (1980-2015), Vol. 54, No. 2, pp. 207211.

4. Ema, M. (2008). Tensile strength of MIGwelded aluminium alloys for structures. Welding International, Vol. 22, No. 4, pp. 199-205.

5. Paik, J.K., et al. (2005). Ultimate compressive strength design methods of aluminum welded stiffened panel structures for aerospace, marine and land-based applications: A benchmark study. Thin-Walled Structures, Vol. 43, No. 10, pp. 1550-1566.

6. Sivam, S., et al. (2016). Investigation exploration outcome of heat treatment on corrosion resistance of AA 5083 in marine application. International Journal of Chemical Sciences, Vol. 14, No. S2, pp. 453-460.

7. Kaufman, J.G. (2000). "Introduction to aluminum alloys and tempers". ASM international.

8. Gungor, B., et al. (2014). Mechanical, fatigue and microstructural properties of friction stir welded 5083-H111 and 6082-T651 aluminum alloys. Materials \& Design (1980-2015), Vol. 56, No. pp. 84-90.
9. Campbell, F.C. (2008).Aluminum, in, F.C. Campbell, Editor.Elements of Metallurgy and Engineering Alloys ASM International: Ohio. pp. $487-508$

10. Oloyede, O. (2012). Feasibility of Replacing Structural Steel with Aluminum Alloys in the Commercial Ship Building Industries in Nigeria. International Journal of Science and Technological Research, Vol. 9, No. 5, pp. 188-204.

11. Ertuğ, B. and L.C. Kumruoğlu. (2015). 5083 type Al-Mg and 6082 type Al-Mg-Si alloys for ship building. American Journal of Engineering Research, Vol. 4, No. 3, pp. 146150.

12. Lin, S., et al. (2010). Annealing behavior of a modified 5083 aluminum alloy. Materials \& Design, Vol. 31, No. 3, pp. 1607-1612.

13. Association, A. International alloy designations and chemical composition limits for wrought aluminum and wrought aluminum alloys. Teal Sheets 2009 cited Access (2009) accesed: 22/7/2020; 1-28. Available from: https://www.aluminum.org/sites/default/files/ Teal\%20Sheet.pdf.

14. Aballe, A., et al. (2003). Influence of the cathodic intermetallics distribution on the reproducibility of the electrochemical measurements on AA5083 alloy in $\mathrm{NaCl}$ solutions. Corrosion science, Vol. 45, No. 1, pp. 161-180.

15. Sanders, R., S. Baumann, and H. Stumpf. (2012). Wrought-Non-Heat-Treatable Aluminum Alloys. Contemporary Research and Applications, eds. AK Vasudevan, RD Doherty (Cambridge, MA: Academic Press, Inc., 1989), Vol. 31, No. 6, pp. 65-105.

16. Rollason, E.C. (1973). "Metallurgy for engineers". $4^{\text {th }}$ ed., Edward Arnold. 